\title{
NEW PERSPECTIVE ARTICLE \\ Can Biological Markers Partially Explain the Link Between the Social Environment and Oral Health?
}

\author{
¿Pueden los marcadores biológicos explicar parcialmente la relación \\ entre el entorno social y la salud oral?
}

Received: 1-V-2018

Accepted: 2-V-2018

Published Online First: 9-V-2018

DOl: https://doi.org/10.15517/ijds.v0i0.33236

\begin{abstract}
Understanding how the social world affects humans' health by "getting under the skin" and penetrating the cells, organs and physiological systems of the body is a key tenet in public health research. Here, we propose the idea that socioeconomic position (SEP) can be biologically embodied, potentially leading to the production of health inequalities in oral health across population groups. Recent studies show that being exposed to chronic stress across the life course could impact our health. Allostatic load (AL) is a composite biological measure of overall physiological wear-and-tear that could allow a better understanding of the potential biological pathways playing a role in the construction of the social gradient in adult health. However, to use biological measures to better understand the mechanisms that construct health inequalities in oral health has not been tested systematically. The purposes of this New Perspective is to discuss the value of using composite biological markers, such as $\mathrm{AL}$, to analyze oral health. This can allow a better understanding of the mechanisms leading to health inequalities in oral health, and add some valuable information for implementing health interventions.
\end{abstract}

\section{KEYWORDS}

Oral health inequalities; Allostatic load; Socioeconomic position; Biological markers; Embodiment. 
Comprender cómo el mundo social afecta la salud de los seres humanos "penetrando bajo la piel" e introduciéndose dentro de las células, los órganos y los sistemas fisiológicos del cuerpo, es un principio clave en la investigación en salud pública. Aquí, proponemos la idea que la posición socioeconómica puede incorporarse biológicamente, lo que puede conducir a la producción de inequidades sociales en salud entre diferentes grupos de población. Estudios recientes muestran que estar expuesto al estrés crónico a lo largo de la vida podría afectar nuestra salud. La carga alostática es una medida biológica compuesta del desgaste fisiológico global del cuerpo que podría permitir una mejor comprensión de las posibles vías biológicas que desempeñan un papel en la construcción del gradiente social en la salud del adulto. Sin embargo, el uso de medidas biológicas para comprender mejor los mecanismos que construyen las inequidades sociales en salud oral, no se ha probado sistemáticamente. El propósito de este boletín de New Perspective es analizar el valor del uso de marcadores biológicos compuestos, como la carga alostática, para analizar la salud oral. Esto puede permitir una mejor comprensión de los mecanismos que conducen a las inequidades sociales en salud oral, y así agregar información valiosa para implementar de manera más adecuada las intervenciones en salud.

\section{PALABRAS CLAVE}

Desigualdades sociales en salud oral; Inequidades sociales en salud oral; Posición socioeconómica; Marcadores biológicos; Incorporación biológica.

This New Perspective article stems from a continuing debate in epidemiological and biomedical research, about how the social world in which we live impacts our health. The health of populations reflects the social hierarchy and economic organization $(1,2)$. To improve it, medical researchers should systematically consider how the social world affects individuals' daily lives. This is crucial for directing and giving context to our research objectives, for a better implementation of effective public health interventions and for improving specific populations' health programs.

Despite being largely preventable, dental diseases continue to represent a major public health challenge in both developed and developing countries. The burden of oral diseases is particularly high among under-privileged groups (3). Across the lifespan, oral diseases negatively impact quality of life $(4,5)$ and social functioning (6), considering their consequences on nutrition (7), infection, pain, speech difficulties (8) and self- esteem (9). Studies have largely documented the link between socioeconomic circumstances and oral health $(3,10,11)$. On average, individuals in the bottom of social hierarchy are those who are more likely to experience oral health problems compared to those on the middle, and they in turn, have worse oral health than those at the top (12). The fine gradient producing health differences on morbidity and mortality according to social class found when analyzing general health, applies to oral health $(12,13)$. This may suggest that the same mechanisms could relate to both general and oral health.

Social epidemiologists have reported three main plausible mechanisms that could explain the social gradient in health. They include the material, behavioral, and psychosocial factors (14). Those mechanisms seems to replicate when analyzing the social gradient in oral health (15): health behaviors (16), psychosocial factors $(17,18)$ and the material/financial factors (19) may account 
for the observed disparities. However, some epidemiological studies have shown that classic determinants are not sufficient for explaining the inequalities observed (20). This may point toward the existence of other mechanisms influencing health, like a potential biological pathway. Nancy Krieger define the notion of embodiment as "how we, like any living organism, literally incorporate, biologically, the world in which we live, including our societal and ecological circumstances" (21). The notion of embodiment posits that every human being is both a social and a biological organism that incorporates the world in which (s)he grows. Analyzing a biological pathway potentially linking the social and the biological, could contribute to a better understanding of how the social world "gets under the skin" to become biological (22). Therefore, the conceptual framework presented by the concept of embodiment may be a useful tool for formulating hypotheses on how oral health inequalities are produced over the life course.

Despite the large number of epidemiological research investigating the link between social status and oral health, few have assessed the extent to which biological markers account for social inequalities in oral health. Growing evidence supports the idea that exposure to stressful conditions over life contributes to physiological dysregulation, subsequently translated into disease, through prolonged activation of stress response systems (23). To partially disentangle the mechanisms between the socioeconomic position across the life course, and later health, some researchers have proposed the use of an integrative biological measure. This may be useful to explore how adverse experiences over the life course may 'get under the skin'. It is suggested that repeated activation of compensatory physiological mechanisms as a response to chronic stress can lead to a physiological wear-and-tear, this is known as allostatic load $(A L)(24)$. In the last two decades, social epidemiologist have used the concept of $A L$ to explain how chronic stress can lead to physiological dysregulation and disease (25). According to AL theory, cumulative and repeated activation of compensatory physiological mechanism in response to chronic stress can lead to a multisystem predisease state represented by a dysregulation of neuroendocrine, metabolic, inflammatory, or cardiovascular parameters (24). Regarding oral health, AL could be a useful biological measure since overall physiological dysregulation could have negative effects on oral health, by triggering oral diseases, or by deteriorating an ongoing disease process. Some evidence can support this idea: i. it has been suggested that poor oral health could cause inflammatory and immune responses (26); ii. chronic diseases has effects on oral health $(27,28)$, and some evidence suggests the existence of a two-way relationship between, for instance, diabetes and periodontitis (29); iii. chronic and dental diseases share a vast majority of risk factors (30); iv. some propose the existence of a relationship between stress, psychosocial factors and periodontal diseases (26). More recently, Borrel showed an associations between $\mathrm{AL}$ and periodontal diseases $(31,32)$. Gomma et al. (33) suggested that, from an aetiological perspective "periodontal disease has consistently been linked to the interplay between plaque and the hostimmune response. Extensive research has shown that while periodontal conditions are initiated by dental plaque, perpetuation of inflammation and the severity and progression of the disease depends upon the effectiveness of the innate immune response to the bacterial biofilm (34)". And regarding caries, they mentioned "is essentially a diet-mediated disease in which host factors, such as immune components in the microbial biofilm and saliva contribute to its progression $(28,35,36) "$. Boyce et al. additionally showed that socioeconomic position, a dysregulation of the hypothalamic-pituitary-adrenal (HPA) axis 
(measured using salivary cortisol), and cariogenic bacteria, were independent factors associated with dental caries in children $(37,38)$.

These few studies add some evidence to the hypothesis of a plausible biological underlying mechanism between the social environment and later oral health, via stress response systems, by modifying local and systemic inflammatory and immune responses. Underlying biological mechanisms are plausible, and they can be captured using different measures. AL intent to be an overall measure that can capture the biological effects of stress responses in the body, that could be also used to characterize oral health. Being an objective measure, $A L$ offers the possibility of comparing results from different contexts and to replicate the studies. This may allow to observe how the physiological responses due to chronic stress can affect oral health in different cultural contexts and population subgroups (by sex, age and ethnicity). However more studies are needed to continue to investigate these hypotheses. In that sense, cohort studies containing biological markers and reliable oral health variables are extremely valuable.

In summary, a growing literature suggests that stress responses could have an impact on overall health, and partially explain the social gradient observed. These same mechanisms could apply to oral health social disparities. Stress responses could affect oral health via some biological mechanisms that have been already described as affecting disease development, such as, inflammatory and immune responses. Finally, the ability to measure the way biological markers relate to oral disease development offers many possibilities regarding public health interventions both at a societal level, by investing in social environments, and at an individual level by preventing diseases through behavioral or treatment interventions.

\section{REFERENCES}

1. Marmot M., Friel S., Bell R., Houweling T. A., Taylor S. Closing the gap in a generation: health equity through action on the social determinants of health. Lancet. 2008; 372 (9650): 1661-9.

2. Marmot M., Wilkinson R., editors. Social Determinants of Health. 2nd ed. Oxford: Oxford University Press; 2006. 376 p.

3. Watt R. G., Listl S., Peres M., Heilmann A. Social inequalities in oral health: from evidence to action. London: University College London; 2015. 42p.

4. Gerritsen A. E., Allen P. F., Witter D. J., Bronkhorst E. M., Creugers N. H. J. Tooth loss and oral health-related quality of life: a systematic review and meta-analysis. Health Qual Life Outcomes. 2010; 8: 126:1-11.

5. Mack F., Schwahn C., Feine J. S., Mundt T., Bernhardt O., John U., et al. The impact of tooth loss on general health related to quality of life among elderly Pomeranians: results from the study of health in Pomerania (SHIP-O). Int J Prosthodont. 2005; 18 (5): 414-9.

6. FDI World Dental Federation. The Challenge of Oral Disease-A call for global action. The Oral Health Atlas. 2nd ed. Geneva; 2015. 120 p.

7. Nowjack-Raymer R. E., Sheiham A. Numbers of natural teeth, diet, and nutritional status in US adults. J Dent Res. 2007; 86 (12): 1171-5.

8. Heilmann A., Tsakos G., Watt R. G. Oral Health Over the Life Course. In: Burtonjeangros C., Editors D. B., Howe L. D., Firestone R., Tilling K., Lawlor D. A., editors. Springer. London: Springer Open; 2015. p. 39-61.

9. Rousseau N., Steele J., May C., Exley C. "Your whole life is lived through your teeth": biographical disruption and experiences of tooth loss and replacement. Sociol Health Illn. 2014; 36 (3): 462-76. 
10. Poulton R., Caspi A., Milne B. J., Thomson WM, Taylor A, Sears MR, et al. Association between children's experience of socioeconomic disadvantage and adult health: a life-course study. Lancet (London, England). 2002; 360 (9346): 1640-5.

11. Thomson W. M., Poulton R., Milne B. J., Caspi A., Broughton J. R., Ayers K. M. S. Socioeconomic inequalities in oral health in childhood and adulthood in a birth cohort. Community Dent Oral Epidemiol. 2004; 32 (5): 345-53.

12. Marmot M., Bell R. Social determinants and dental health. Adv Dent Res. 2011; 23 (2): 201-6.

13. Sabbah W., Tsakos G., Chandola T., Sheiham A., Watt R. G. Social gradients in oral and general health. J Dent Res. 2007; 86 (10): 992-6.

14. Bartley M. Health Inequality: An Introduction to Theories, Concepts and Methods. Cambridge: Polity Press; 2003. 224 p.

15. Watt R. G. Social determinants of oral health inequalities: implications for action. Community Dent Oral Epidemiol. 2012; 40 Suppl 2:44-8.

16. Sabbah W., Tsakos G., Sheiham A., Watt R. G. The role of health-related behaviors in the socioeconomic disparities in oral health. Soc Sci Med. 2009; 68 (2): 298-303.

17. Baker S. R., Mat A., Robinson P. G. What Psychosocial Factors Influence Adolescents' Oral Health? J Dent Res. 2010; 89 (11): 1230-5.

18. Armfield J. M., Mejía G. C., Jamieson L. M. Socioeconomic and psychosocial correlates of oral health. Int Dent J. 2013; 63 (4): 202-9.

19. Fantin R., Delpierre C., Kelly-Irving M., Barboza Solis C. Early socioeconomic conditions and severe tooth loss in middleaged Costa Ricans. Community Dent Oral Epidemiol. 2018; 46 (2):178-84.

20. Gallo V., Mackenbach J. P., Ezzati M., Menvielle G., Kunst A. E., Rohrmann S., et al. Social inequalities and mortality in europe - results from a large multi-national cohort. PLoS One. 2012; 7 (7).

21. Krieger N. Embodiment: a conceptual glossary for epidemiology. J Epidemiol Community Health . 2005; 59 (5): 350-5.

22. Hertzman C., Boyce T. How experience gets under the skin to create gradients in developmental health. Annu Rev Public Health. 2010; 31 (1): 329-347.

23. McEwen B. S., Stellar E. Stress and the individual. Mechanisms leading to disease. Arch Intern Med. 1993; 153 (18): 2093-101.

24. Juster R-P, McEwen B. S., Lupien S. J. Allostatic load biomarkers of chronic stress and impact on health and cognition. Neurosci Biobehav Rev. 2010; 35 (1): 2-16.

25. Karlamangla A. S., Singer B. H., McEwen B. S., Rowe J. W., Seeman T. E. Allostatic load as a predictor of functional decline. MacArthur studies of successful aging. J Clin Epidemiol. 2002; 55 (7): 696-710.

26. Sheiham A., Watt R. G. The common risk factor approach: a rational basis for promoting oral health. Community Dent Oral Epidemiol. 2000; 28 (6): 399-406.

27. Cekici A., Kantarci A., Hasturk H., Van Dyke T. E. Inflammatory and immune pathways in the pathogenesis of periodontal disease. Periodontol 2000. 2014; 64 (1): 57-80.

28. Taubman M. A., Valverde P., Han X., Kawai T. Immune response: the key to bone resorption in periodontal disease. J Periodontol. 2005; 76 (11 Suppl): 2033-41.

29. Chavarry N. G. M., Vettore M. V., Sansone C., Sheiham A. The relationship between diabetes mellitus and destructive periodontal disease: a meta-analysis. Oral Health Prev Dent. 2009; 7 (2): 107-27.

30. Preshaw P. M., Alba A. L., Herrera D., Jepsen S., Konstantinidis A., Makrilakis K., et al. Periodontitis and diabetes: a two-way relationship. Diabetologia. 2012; 55 (1): 21-31. 
31. Vasiliou A., Shankardass K., Nisenbaum R., Quiñonez C. Current stress and poor oral health. BMC Oral Health [Internet]. 2016; 2; 16 (1): 88.

32. Peruzzo D. C., Benatti B. B., Ambrosano G M. B., Nogueira-Filho G. R., Sallum E. A., Casati M. Z., et al. A systematic review of stress and psychological factors as possible risk factors for periodontal disease. J Periodontol. 2007; 78 (8):1491-504.

33. Borrell L. N., Crawford N. D. Social disparities in periodontitis among US adults: the effect of allostatic load. J Epidemiol Community Health. 2011; 65 (2): 144-9.

34. Gomaa N., Glogauer M., Tenenbaum H., Siddiqi A., Quiñonez C. Social-Biological Interactions in Oral Disease: A "Cells to Society" View. Divaris K, editor. PLoS One. 2016; 11 (1): e0146218.

35. Ying G., Ryan M. Overview of Periodontal Disease: Causes, Pathogenesis and
Characteristics. In: Genco R., Williams R., editors. Periodontal Disease and Overall Health: A Clinician's Guide. Yardley, Pennsylvania: Professional Audience Communications, Inc; 2010.

36. Ji S., Kim Y., Min B-M, Han S. H., Choi Y. Innate immune responses of gingival epithelial cells to nonperiodontopathic and periodontopathic bacteria. J Periodontal Res. 2007; 42 (6): 503-10.

37. Hirschfeld J., Dommisch H., Skora P., Horvath G., Latz E., Hoerauf A., et al. Neutrophil extracellular trap formation in supragingival biofilms. Int J Med Microbiol. 2015; 305 (4-5): 453-63.

38. Fidalgo T. K. da S., Freitas-Fernandes L. B., Ammari M., Mattos C. T., de Souza I. P. R., Maia L. C. The relationship between unspecific s-IgA and dental caries: A systematic review and meta-analysis. J Dent . 2014; 42 (11): 1372-1381.

\section{Cristina Barboza Solís MSc, PhD1 \\ 1. Facultad de Odontología, Universidad de Costa Rica. MSc Clinical Epidemiology, PhD Social Epidemiology. \\ Correspondence to: cristina.barbozasolis@ucr.ac.cr}

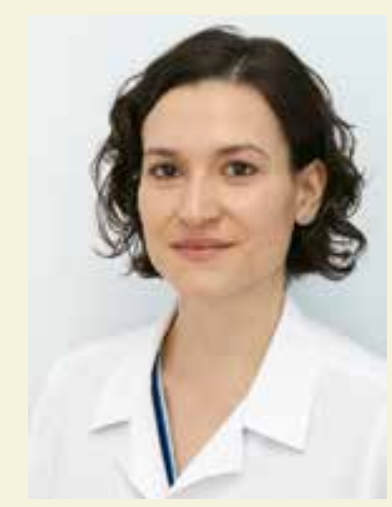

Attribution (BY-NC) - (BY) You must give appropriate credit, provide a link to the license, and indicate if changes were made. You may do so in any reasonable manner, but not in any way that suggest the licensor endorses you or your use. (NC) You may not use the material for commercial purposes. 